\title{
Optimization of the technology for the production of foam glass aggregate
}

\author{
Igor Bessonov ${ }^{1, *}$, Aleksey Zhukov ${ }^{2}$, Ekaterina Shokodko ${ }^{2}$, and Aleksandr Chernov ${ }^{2}$ \\ ${ }^{1}$ Research Institute of Building Physics of the Russian Academy of Architecture and Building \\ Sciences, 21, Lokomotivniy Tr., 127238, Moscow, Russia \\ ${ }^{2}$ Moscow State University of Civil Engineering, 26, Yaroslavskoye Sh., 129337, Moscow, Russia
}

\begin{abstract}
The article presents the results of a study of the state of production of a foam glass and the nomencla-ture of its products. It is shown that it is expedient to use the recycled glass obtained from the bottle battle, the defective glass and the double-glazed windows as a raw material for the production of the foam-glass. The re-quirements are formulated for glasses, which should have low viscosity values in the range of foaming tempera-tures. The features of the technology for the production of the foam glass aggregate at the specialized lines are outlined. The technology features are the composition of the charge and temperature conditions of burning. The mixture for the production of the foam glass aggregate consists of glass flour, organomineral blowing agent con-taining water and food glycerin, as distinct from the slab foam glass, where soot or coke is used as a blowing agent. The results confirm the effectiveness of the use of the foam glass aggregate as a soundproofing backfill for floors. Currently, about $70 \%$ of the foam glass aggregate is used for roofs and stylobates; the rest is used in landscape design, road construction, foundations and major repair. In the future, the areas of application of the foam glass aggregate can be significantly expanded in the direction of building systems, lightweight aggregates, etc., which involves in-depth studies of the properties of this material.
\end{abstract}

\section{Introduction}

Foam glass aggregate is used as a backfill for warming the foundations of low-rise buildings, brick walls with hollow masonry, perimeter walks, flat roofs, as well as strengthening the weak soils and a sub -ballast layer of the road surface. Foam glass crushed stone, produced on specialized lines, has a density of 120 to $200 \mathrm{~kg} / \mathrm{m}^{3}$ and a grain size $40-60 \mathrm{~mm}$ [1-3]. Foam glass aggregate is covered with layers of $10-15 \mathrm{~cm}$ with layerby-layer compaction.

For the first time, the foam glass as a building material was mentioned by Academician I.I. Kitaygo-rodsky at the All-Union Conference on Standardization and Production of New Materials in Moscow in 1932. Soon, a technology was proposed in the USSR. Areas of application of foam glass were outlined [4-6]. In the 1930s, intensive work began and patents were obtained for the production of foam glass in France, Czechoslova-kia, the

*Corresponding author: bessonoviv@mail.ru 
USA, England and Germany. During the Second World War, research and technological work were dis-continued everywhere with the exception of the United States. This allowed the United States to master the large-scale production of foam glass, mainly for the needs of the Navy, and then for many years to become a leader in the production and research of this technology [7-9].

Recently, in Russia, high-tech industrial production of foam glass products of the NEOPORM brand was organized by STES-Vladimir company (Vladimir), IZOSTEK (Krasnoyarsk), foam glass aggregate by the company ICM Glass Kaluga (Kaluga Region) and others.

\section{Materials and Methods}

As a raw material for the production of the foam glass, recycled glass obtained from bottle fight, defec-tive auto glass and double -glazed windows is used. Glass waste is crushed and cleaned of impurities, the result-ing homogeneous mixture (mixture) on a conveyor enters a special tunnel furnace. As a result of heating to $800-900^{\circ} \mathrm{C}$, glass particles soften to a viscous-liquid state, and carbon oxidizes with the formation of gaseous $\mathrm{CO}_{2}$, which foams the glass. Thus, foam glass is a highly porous rigid cellular material obtained by the method of high -temperature foaming of softened sodium-calcium-silicate glass, which is a highdensity foam; the disper-sion medium is a glass.

The analysis of glasses recommended by International Research to obtain high-quality foam glass per-formed that the greatest use in the production of foam glass was found in glasses synthesized in the systems $\mathrm{SiO}_{2}-\mathrm{Al}_{2} \mathrm{O}_{3}-\mathrm{MgO}-\mathrm{CaO}-\mathrm{R}_{2} \mathrm{O}$ and $\mathrm{SiO}_{2}-\mathrm{B}_{2} \mathrm{O}_{3}-\mathrm{MgO}$ - $\mathrm{CaO}-\mathrm{R}_{2} \mathrm{O}$. It can be concluded that aluminosilicate and aluminoborosilicate glasses most fully satisfy the requirements of foam glass. In Russia, glass melt is most often used for the production of heat-insulating foam glass, which in chemical composition is close to aluminum-magnesium window glass [10-12].

The glass should have the low viscosity values in the range of the foaming temperatures. This is neces-sary so that the glass is densely sintered before the start of gas evolution and is easily stretched in thin walls. Glass should not be prone to crystallization, as it increases the viscosity and contributes to the breakthrough of the walls of individual pores and the formation of a labyrinthine structure in the porous material. Glass should have low surface tension so that it does not strongly prevent the walls from stretching. Glass must have a high oxidative potential. To do this, it requires a large content of dissolved gases $\mathrm{O}_{2}$ and $\mathrm{SO}_{3}$.

The most responsible of the main technological processes is the sintering and porization of the material. At this time, a number of physical and physicochemical processes take place, requiring a combination of the most important factors that determine the necessary structure formation $[13,14]$.

At a temperature of intense gas generation, the glass melt should be characterized by sufficient viscosi-ty, ensuring the continuity of the formed films (interpore partition) and low surface tension, contributing to the thinning of these films. This is ensured by the temperature of the onset of the intense gas evolution (type of the blowing agent) and the chemical composition of the glass melt, which determines the change in its rheological properties upon heating.

The composition of the mixture for the foam glass aggregate consists of glass flour, food glycerin (the blowing agent) and the water (the liquid component is $10-12 \%$ ), in contrast to plate foam glass, where soot or coke is used as a blowing agent $[15,16]$.

For the organization and optimization of the technological process, it is important to determine the fun-damental relationships between the dispersion of the glass charge and its firing temperature. In order to establish the analytical dependencies linking these 
parameters, an experiment was organized (Table 1). At the same time, the flow rate of the blowing agent remained constant and did not affect the result. As a response function (Y), the compressive strength of foam glass aggregate was adopted at $25 \%$ deformation.

Table 1. The experiment conditions.

\begin{tabular}{|c|c|c|c|c|c|}
\hline Name of the factor & \multirow{2}{*}{$\begin{array}{c}\text { Symbol } \\
\mathbf{X i}\end{array}$} & $\begin{array}{c}\text { The average value } \\
\text { of the factor Xi }\end{array}$ & \multicolumn{2}{|c|}{$\begin{array}{c}\text { Range of } \\
\text { variation Xi }\end{array}$} & \multicolumn{2}{|c|}{$\begin{array}{c}\text { Factor values at } \\
\text { the levels }\end{array}$} \\
\cline { 5 - 7 } & & $\mathrm{-1}$ & $\mathbf{+ 1}$ \\
\hline $\begin{array}{c}\text { The specific surface of the } \\
\text { glass charge, } \mathrm{g} / \mathrm{cm} 3\end{array}$ & $\mathrm{X} 1$ & 2500 & 500 & 2000 & 3000 \\
\hline The burning temperature, oC & $\mathrm{X} 2$ & 850 & 50 & 800 & 900 \\
\hline
\end{tabular}

The experiment was carried out according to the rotatable D-optimal plan, which underlies the derivation of non-linear regression equations.

\section{Results}

The implementation of the experiment and the statistical processing of the experimental results allowed us to obtain the dependence of the strength of foam glass aggregate on the technological parameters:

$$
\mathrm{Y}=830+32 \mathrm{X}_{1}+22 \mathrm{X}_{2}+14 \mathrm{X}_{1} \mathrm{X}_{2}-6 \mathrm{X}_{2}^{2}
$$

The confidence interval calculated using the Student's test and the variance of parallel experiments was $b=4$. The modulus of the coefficient of the equation at $\mathrm{X}_{1}^{2}$ turned out to be less than $b$, was adopted insignificant, and equaled 0 .

The analysis of the regression equation allows us to draw the following conclusions. In the intervals es-tablished in the experiment, the specific surface of the glass charge (coefficient at $X_{1}$ equal to 32), that is, its fineness of grinding, has the greatest influence on the result. The burning temperature affects the increase in strength characteristics to a lesser extent, while at higher temperatures its influence on the result (the coefficients at $\mathrm{X}_{2}$ and $\mathrm{X}_{2}{ }^{2}$ are 22 and -6 , respectively). Noteworthy is the significant positive effect revealed for the pair $\left(\mathrm{X}_{1} \mathrm{X}_{2}\right)$ interaction, the so-called the synergistic effect.

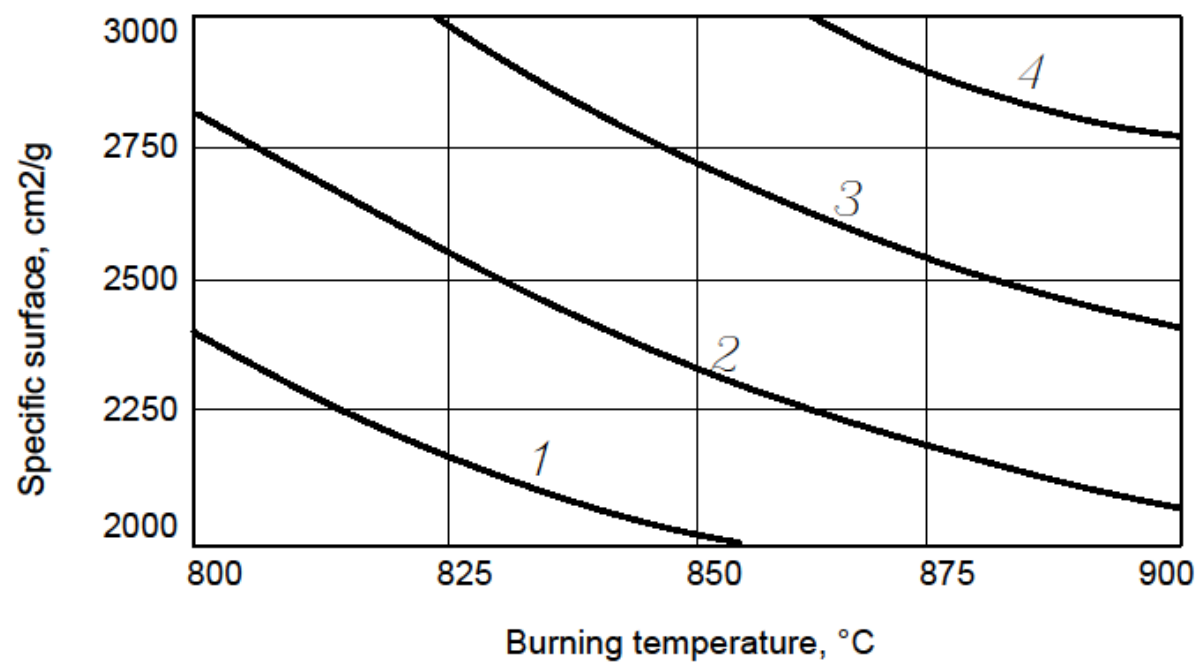

Fig. 1. The dependence of compressive strength at $25 \%$ strain on the specific surface and the burning tempera-ture of the mixture, $\mathrm{kPa}: 1-840 ; 2-850 ; 3-860 ; 4-870$. 
The results were taken into account when choosing the technological process parameters.

The material obtained as a result of optimization of the technology was tested according to acoustic cha-racteristics. One of the promising areas of application of the foam glass aggregate is its use as a backfill in the insulation of building structures (mainly interfloor ceilings, ceilings for inverse and exploited roofs), which im-poses additional requirements on the material in terms of heat and sound insulation. A study of the acoustic insu-lation backfill from the foam-glass aggregate of a fraction of 5-20 mm with a thickness of $60 \mathrm{~mm}$ was conducted in order to determine the characteristics of its sound-insulating properties and the field of application.

A fragment of a floating screed was mounted in the reverberation chambers for testing the flooring of a standard reinforced concrete slab with a thickness of about $140 \mathrm{~mm}$. The screed was made of a cement-sand plate with a thickness of $40 \mathrm{~mm}$ and a surface density of about $100 \mathrm{~kg} / \mathrm{m}^{2}$. The plate was laid on a continuous layer of backfill from foam-glass aggregate of a fraction of 5-20 $\mathrm{mm}$ and a thickness of $60 \mathrm{~mm}$.

The frequency characteristics of the reduced levels of impact noise under the flooring $\mathrm{L}_{\mathrm{f}(\mathrm{o})}(\mathrm{f})$ and under the flooring with the screed laid on the layer of the foam- glass aggregate $\mathrm{L}_{\mathrm{f}(1)}$ were determined. Then, the reduc-tion values of the adjusted levels of the impact noise with the floating screed were calculated by the formula.

The results of the measurements in the form of the frequency characteristics of the adjusted levels of the impact noise $\mathrm{L}_{0 \mathrm{n}}$ and $\mathrm{L}_{\mathrm{n} 1}$, as well as the values of the reduction in the adjusted levels of impact noise of the investigated floating screed $\Delta \mathrm{L}_{\mathrm{n}}(\mathrm{f})$ are presented in the Table 2. The index of improvement in impact noise insula-tion by a screed laid on an elastic soundproofing layer, $\mathrm{dB}$, is determined by comparing the frequency response $\Delta \mathrm{L}_{\mathrm{n}}(\mathrm{f})$ with the normative curve (Table 2).

Table 2. The adjusted levels of the impact noise under the ceiling.

\begin{tabular}{|c|c|c|c|}
\hline \multirow{2}{*}{$\begin{array}{c}\mathbf{1 / 3} \text { octave band } \\
\text { frequen cy, Hz }\end{array}$} & $\begin{array}{c}\text { The adjusted levels of impact noise under the ceiling of reinforced concrete and under } \\
\text { the ceiling with a screed laid over a layer of granules of the foam glass, dB }\end{array}$ \\
\cline { 2 - 4 } & $\begin{array}{c}\text { Reinforced concrete floor } \\
\text { slab with a thickness of } \mathbf{1 4 0} \\
\mathbf{m m}, \mathbf{d B}\end{array}$ & $\begin{array}{c}\text { Screed with a surface density of } \\
\mathbf{m}=\mathbf{1 0 0} \mathbf{~ k g} / \mathbf{m}^{2} \text {, laid over a 60 } \\
\text { mm thick layer of foam glass } \\
\text { aggregates on the reinforced } \\
\text { concrete slab, dB }\end{array}$ & $\begin{array}{c}\text { The impact noise reduction, } \\
\Delta \mathbf{L}_{\mathbf{n}}(\mathbf{f})\end{array}$ \\
\hline 100 & 73.7 & 67.0 & 6.70 \\
\hline 125 & 72.0 & 72.3 & -0.30 \\
\hline 160 & 71.5 & 68.3 & 3.20 \\
\hline 200 & 73.0 & 69.2 & 3.80 \\
\hline 250 & 73.0 & 68.0 & 5.00 \\
\hline 320 & 72.0 & 66.2 & 5.30 \\
\hline 400 & 74.0 & 66.0 & 8.00 \\
\hline 500 & 75.3 & 61.5 & 13.80 \\
\hline 630 & 75.2 & 58.5 & 16.70 \\
\hline 800 & 76.7 & 57.0 & 19.70 \\
\hline 1000 & 76.8 & 55.3 & 21.50 \\
\hline 1250 & 77.2 & 51.7 & 25.50 \\
\hline 1600 & 77.6 & 40.0 & 28.60 \\
\hline 2000 & 77.5 & 47.8 & 29.70 \\
\hline 2500 & 77.7 & 43.3 & 34.40 \\
\hline 3200 & 7.0 & 35.0 & 41.00 \\
\hline & insulation improvement index & $\Delta \mathrm{L}_{\mathrm{nw}}=21 \mathrm{~dB}$ \\
\hline
\end{tabular}




\section{Discussions}

The technological features of the manufacture of the foam glass aggregate from the technology of slab products are more stringent requirements for fineness of grinding the foam glass mixture, monitoring the burning regime and the absence of burning as such.

The main raw materials for the foam-glass aggregate are the bottle (priority is white, green) and flat glass, which are brought to the warehouse of raw materials from the landfills. From the warehouse, the raw ma-terials are loaded into the receiving hopper and into the dryer, where it is dried at $80-90^{\circ} \mathrm{C}$, and then into the mill, where it is ground to the state of glass flour with a size of 80 microns. Then, with the help of a magnet, metal objects are removed (for example, iron lids from cans). The finished glass mill is crushed, dried, sieved (less than 100 microns) and sent to storage silos for 2-3 days.

The finished glass flour gets into the mixer, where it is mixed with additives (liquid glass $-80 \%$, glyce-rin - 9\%, water - $6 \%$ ). The additives are dosed depending on the field of application of the finished product, i.e. used in road construction, industrial, agricultural, etc.

The glass canvas (necessary so that the product does not adhere to the tape) is moistened with kaolin emulsion (water is mixed with clay), the glass powder is laid on it, compacted and sent to the tunnel oven with a length of $50 \mathrm{~m}$ along the transport tape (Fig. 2). The speed and temperature in the furnace are set depending on the required density and strength of the product. In the furnace, water evaporates, glycerin burns out and the swelling occurs.

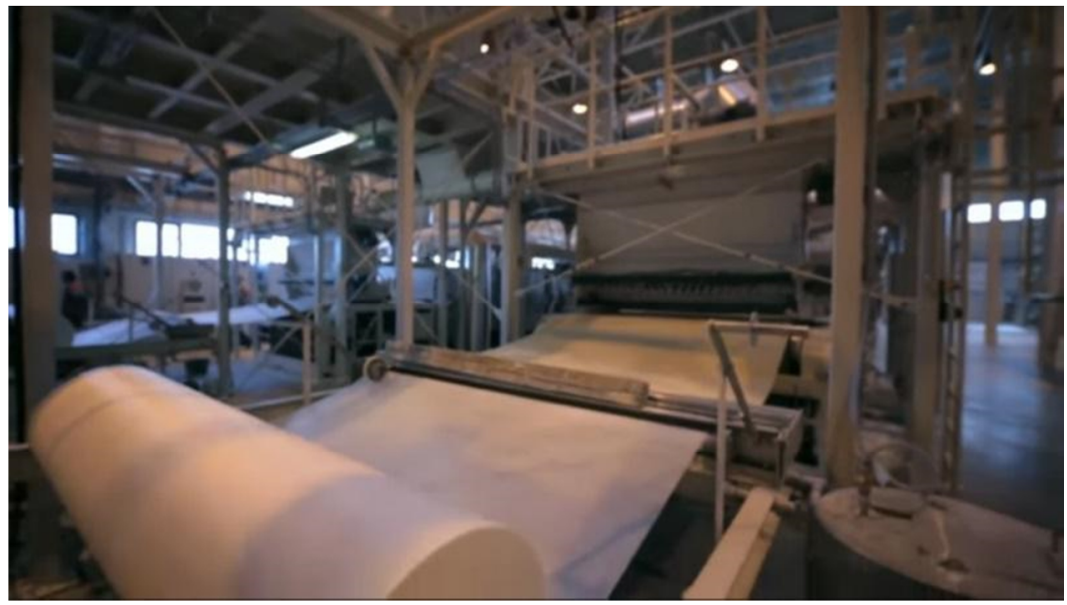

Fig. 2. Technology of the foam glass aggregate - a production line. 


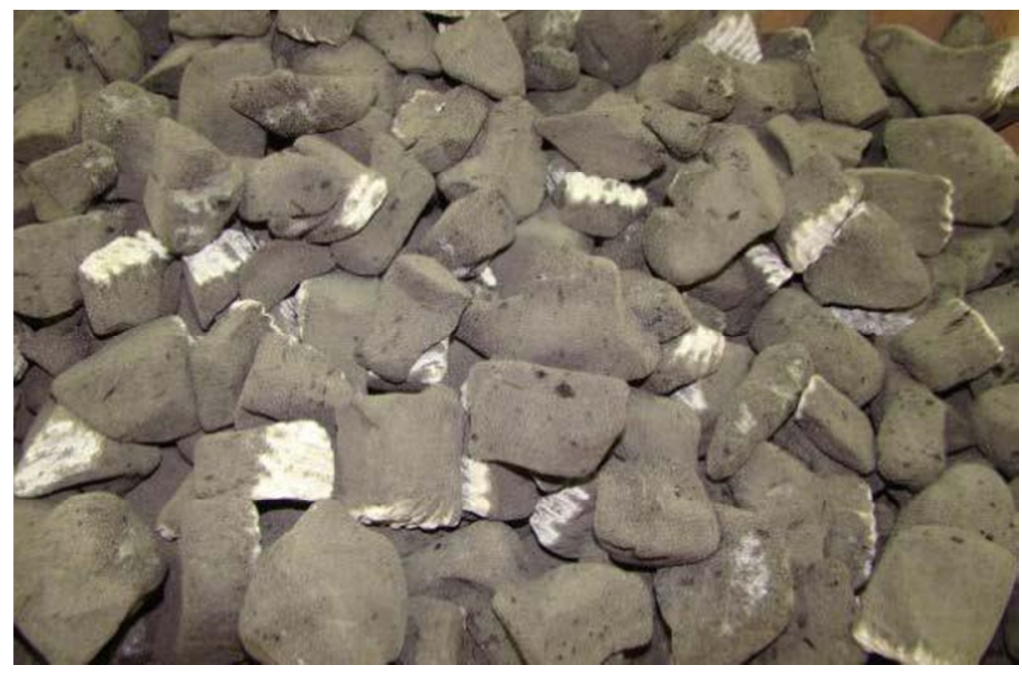

Fig. 3. The foam glass aggregate produced on a specialized line of ICM Glass Kaluga LLC.

A tunnel kiln consists of several modules with different temperatures. The temperature in the furnace reaches up to $950^{\circ} \mathrm{C}$. First, the mixture is sintered, passes into the liquid phase, becomes elastic, viscosity is lost, and it swells (the higher the temperature and pressure, the more the product swells). In the last two zones, there are no burners in the furnace and the temperature is $50 \pm 10^{\circ} \mathrm{C}$. Due to the sudden cooling, the elastic cake

is covered with a white crust. The material leaves the melting furnace in the form of a finished product and en-ters the street, where it cracks during the day (Fig. 3). Finished material is stored in open warehouses. The fi-nished product has a bulk density of 120 to $200 \mathrm{~kg} / \mathrm{m}^{3}$ and compressive strength at $25 \%$ relative strain of $850 \mathrm{kPa}$.

The acoustic tests of the samples of the backfill from the foam-glass aggregate justified that, according to the values of the acoustic characteristics, they all belong to the class of effective sound-insulating cushioning materials. The use of the soundproofing backfill from foam-glass aggregate of a fraction of 5-20 mm and a thickness of $60 \mathrm{~mm}$ in the structures of floating screeds provides an index of improvement in impact noise insu-lation of $21 \mathrm{~dB}$, which ensures compliance with regulatory requirements for sound insulation of floor floors in residential and public buildings .

Over the past few years, the domestic foam glass market has been showing steady growth rates. The reason for the high market growth in 2015-2016 is the establishment of one of the largest foam glass crushed stone production in the world - the company ICM Glass Kaluga with a production capacity of 300 thousand $\mathrm{m}^{3}$ per year.

The dynamics of production of the foam glass aggregate in Russia, used as a heatinsulating material in the construction industry, is presented in Fig. 4. 


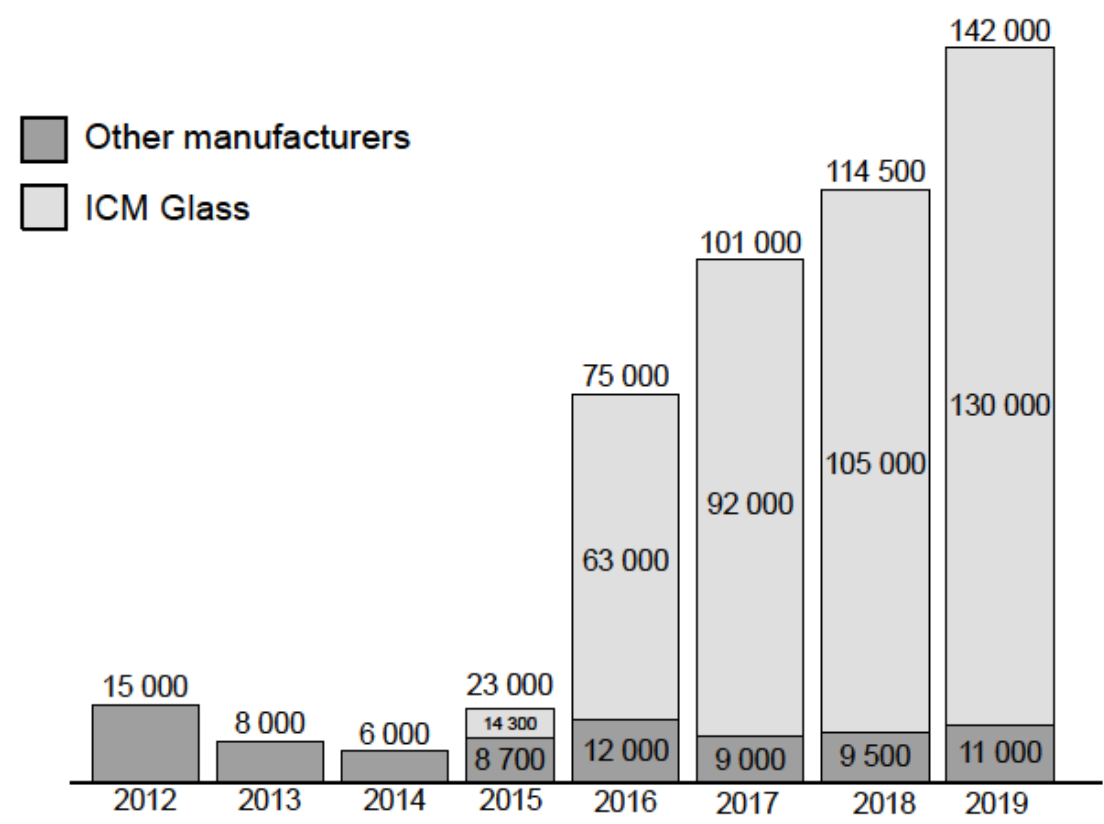

Fig. 4. The dynamics of the production of foam glass rubble in Russia for 2012-2019, $\mathrm{m}^{3}$.

About $30 \%$ of all foam glass aggregate falls on roofs and about $40 \%$ - on stylobates. The remaining vo-lume is used in landscaping, road construction, in the overhaul of apartment buildings and foundations.

The forecast shows that, due to its properties, for the period 2018-2022 years the foam glass aggregate will occupy more than $2 \%$ of the total market of the heat-insulating materials and will amount to at least 1 mil-lion $\mathrm{m}^{3}$. At the same time, due to the high level of logistics costs (a reasonable transport distance is 400-500 km), each of the largest consumption markets in Russia (Central Federal District, North-Western Federal District, Volga Region, Ural, Siberia) will have its own local producer of foam glass aggregate, which will provide its region.

\section{Conclusions}

It is advisable to use recycled glass obtained from bottle battles, defective glasses and double-glazed windows as raw materials for the production of the foam glass aggregate.

The features of the technology for the production of the foam glass aggregate on the specialized lines are composed of the mixture and the temperature regime of the burning. The composition of the charge for foamed glass rubble consists of the glass flour and the organomineral additive - a blowing agent. The consump-tion and content of the components of the additive (water glass, glycerin and water) varies depending on the re-quired average density of foam glass, as well as the intended field of application: for road, industrial, agricultural construction, etc.

The carriedout optimization solutions based on the methods of mathematical statistics and statistical processing of the experimental results made it possible to determine the influence of technological factors on the result and optimize the choice of these factors. A positive synergistic effect was revealed from the combined effect of the specific surface and firing temperature on the strength of foam glass aggregate.

The acoustic tests of the samples of backfill from foam-glass rubble justified that, according to the val-ues of the acoustic characteristics, they all belong to the class of 
effective sound-insulating cushioning materials. The use of the soundproofing backfill from foam-glass aggregate of a fraction of 5-20 mm and a thickness of $60 \mathrm{~mm}$ in the structures of floating screeds provides an index of improvement in impact noise insulation of $21 \mathrm{~dB}$, which ensures compliance with regulatory requirements for sound insulation of floor floors in residential and public buildings.

The forecast shows that by 2022 the foam glass aggregate will occupy more than $2 \%$ of the total market of heat-insulating materials and will be at least 1 million $\mathrm{m}^{3}$.

Currently, about $30 \%$ of all the foam glass aggregate falls on roofs and about $40 \%-$ on stylobates. The direction for insulation of floors in floating floor systems is also developing. The remaining volume is used in landscape design, road construction, in the overhaul of apartment buildings and foundations. In the future, the areas of application of the foam glass aggregate can be significantly expanded in the direction of building sys-tems, lightweight aggregate, etc., which suggests further research on the properties of this material.

\section{References}

1. N. Umnyakova, I. Bessonov, A. Zhukov, E. Zinoveva, MATEC Web of Conferences, ICMTMTE 2019 (2019) DOI: https://doi.org/10.1051/ matecconf/201929800012

2. N. Umnyakova, I. Bessonov, A. Zhukov, E. Zinoveva, MATEC Web of Conferences, ICMTMTE 2019, $00013 \quad$ (2019) DOI: https://doi.org/10.1051/ matecconf $/ 201929800015$

3. B. Efimov, S. Isachenko, M.-B. Kodzoev, G. Dosanova, E. Bobrova, MATEC Web of Conferences, 01032 (2019) DOI: https://doi.org/10.1051/e3sconf/201911001032

4. E. Bernardo, F. Albertini, Ceramics Interatinal. 32, 603-608 (2006)

5. E. Sousa, Materials Science and Engineering doi.org/10.1016/j.msea.2007.05.098

6. I.V. Bessonov, B.I. Bulgakov, O.A. Larsen, O.V. Puchka, S.S. Vaysera, IOP Conf. Series: Materials Science and Engineering 463 (2018) doi:10.1088/1757899X/463/4/042030

7. A. Medvedev, E. Bobrova, A. Poserenin, E. Zarmanyan, MATEC Web of Conferences 170 (2018) DOI: https://doi.org/10.1051/matecconf/201817003018

8. B.M. Rumyantsev, A.D. Zhukov, T.V. Smirnova, Vestnik MGSU 3, 108-114 (2012) DOI: 10.22227/1997-0935.2012.3.108-114

9. A.D. Zhukov, Ye.Yu. Bobrova, D.B. Zelenshchikov, R.M. Mustafaev, A.O. Khimich, Advanced Materials, Structures and Mechanical Engineering 1025-1026, 1031-1034 (2018) DOI: https://doi.org/10.1051/matecconf/201825101016

10. B.M. Rumiantcev, A.D. Zhukov, D.B. Zelenshikov, A.S. Chkunin, K.K. Ivanov, Yu.V. Sazonova, MATEC Web of Conferences $\mathbf{8 6}$ (2016) DOI: http://dx.doi.org/10.1051/matecconf/ 20168604027

11. A. Medvedev, E. Bobrova, A. Poserenin, E. Zarmanyan MATEC Web of Conferences, 03018 (2018) DOI: https://doi.org/10.1051/matecconf/201817003018

12. E.R. Pyataev, A.A. Medvedev, A.I. Poserenin, M.A. Burtseva, E.A. Mednikova, V.M. Mukhametzyanov, IPICSE (2018) DOI: https://doi.org/10.1051/matecconf/201825101012

13. A. Medvedev, E. Bobrova, A. Poserenin E. Zarmanyan, MATEC Web of Conferences 170, 03018 (2018) 
14. A. Pilipenko, E. Bobrova, B. Efimov, MATEC Web of Conferences, ICMTMTE 2019, 00091 (2019) DOI: https://doi.org/10.1051/matecconf/201929800091

15. P. Gudkov, P. Kagan, A. Pilipenko, E.Yu. Zhukova, E.A. Zinovieva, N.A. Ushakov, MATEC Web of Conferences, ICMTMTE 2019, 01039 (2019) DOI: https://doi.org/10.1051/e3sconf/20199701039

16. E.R. Pyataev, A.Y. Ushakov, MATEC Web of Conferences, ICMTMTE 2019, 00133 (2019) DOI: https://doi.org/10.1051/matecconf/201929800133 